\title{
Date palm value chain development and the control of red palm weevil in Egypt
}

\author{
Mohamad Kamal Abbas ${ }^{1}$ and Thaer Yaseen ${ }^{2}$ \\ (1) Plant Protection Research Institute, Agric. Res. Center, Dokki, Giza, Egypt, email: Mohamed.kma155@yahoo.com; \\ (2) Plant Protection Officer, Regional Office for the Near East and North Africa Region (RNE), Cairo, Egypt.
}

\begin{abstract}
Abbas, M.K. and Th. Yaseen. 2019. Date palm value chain development and the control of red palm weevil in Egypt. Arab Journal of Plant Protection, 37(2): 156-157.

Egypt is ranked first in date palm production worldwide, with 16 million date palms. Red palm weevil (RPW) Rhynchophorus ferrugineus (Olivier) (Coleoptera: Curculionidae) is considered the main pest of date palm in Egypt, and was recorded for the first time in this country in 1992 in date palm plantations of Sharkia and Ismailia Governorates. Infestation with this pest is now spread to all 26 governorates in Egypt, and the infestation rate ranges from 2\% to 35\%. FAO supported a technical support project (TCP/EGY/3603) on Date Palm Value Chain Development in Egypt, with main activities in the governorates of Siwa Oasis, El-Kharga, Paris Oasis, El-Dakhla, AlBaharya Oasis, Aswan, Kefr El-Sheikh and Beheria Governorates. One of the project components was to provide assistance for RPW control. The project provided training for more than 3,000 persons (extension workers, farmers, and research workers) from Siwa Oasis, New Valley and Wahat Baheria oases, Aswan and Kefr El-Sheikh Governorates. Training sessions focused on the control of red palm weevil, fruit pests in the field and in storage, as well as on diseases that infect palm trees. The practical training was conducted at one of the palm farms. Based on visual inspection, trainees were able to identify different date palm pests and diseases. Methods of pest control, especially red palm weevil, were illustrated. Al-nakhalin 120 trainees from Siwa Oasis and New Valley (El-Khargaand El Dakhla direction) were given practical and theoretical training on all agricultural and control operations in 22 extension fields (20 fields in Siwa and 2 in ElKhargaand El-Dakhla). Control program implemented during different months ofthe year included: (i) control of pests that started to cause problems in recent years such as Phonapatefrontasi, Oligonichusafrasiaticus and arlatoriablancherd, (ii) biological control of date fruit pests, (iii) control of pests that affect dates during storage and processing. Training also included how to identify symptoms of different pest infestations. Five brochures (fruit pests in thefield, date palm diseases, storage pests,date palm borers in Egypt, and red palm weevil), in addition to a manualfor the control of red palm weevil were prepared. Scientific material for the training courses related to red palm weevil, frond palm borer and fruit stalk borer, disease and fruit pests behavior, common symptoms and control methods such as preventive measures, use of pesticides, light traps and biological control agents were also prepared. During project implementation, a report on the most important pests and diseases in the project work area was prepared, and included the following pests: Oligonichusafrasiaticus, Parlatoriablancherdi, Arenipsessabell, Batrachedraamydraula, Ephesteacalidellaguer, EphestiaCautella, Rhynchophorusferrugineus, Oryzaephilussurinamens, Amitermisdesertorium and Coccotrypesdactyliperda. In addition, a work plan for their control was also prepared.A questionnaire on pests and diseases to collect and analyse data from Siwa Oasis was also prepared. Furthermore, a work planto control date palm pests in Siwa oasis was prepared with assistance from an international expert. Training twenty trainees to train 2,000 farmers (TOT) on IPM ofdate palm pests was achieved. Furthermore, 1750 infested palm trees in Baharya and Siwa were treated using gasoline drills.Field experiments on integrated RPW management were implemented, using aggregation pheromone traps, injection of pesticides in infested palms with continued pest monitoring.

Keywords: Red palm weevil, control, date palm, value chain, training.
\end{abstract}

عباس، محمد كمال وثائر ياسين. 2019. تطوير سلسلة قيمة التمور ومكافحة سوسة النخيل الحمراء في مصر. مجلة وقاية النبات العربية، 157-156:(2)37

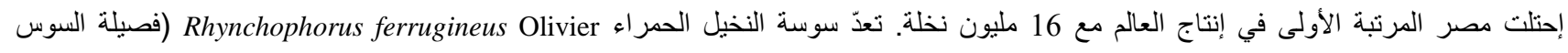

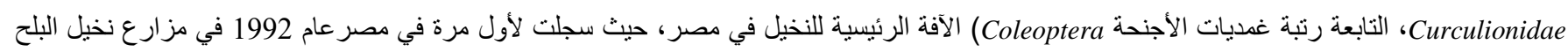

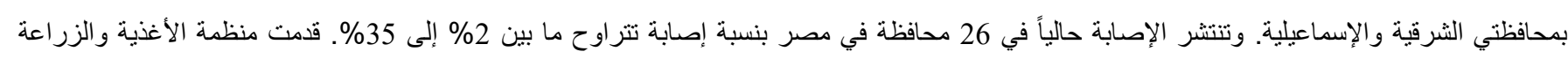

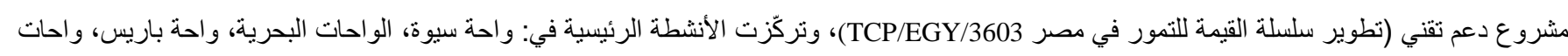

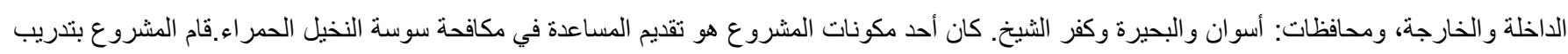

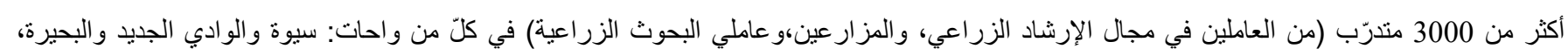

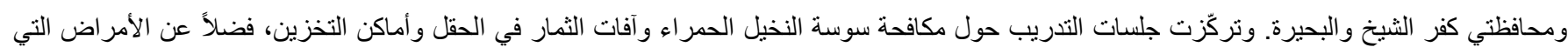

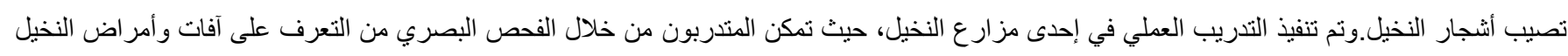

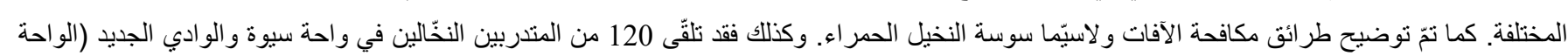

http://dx.doi.org/10.22268/AJPP-037.2.156157

(C) 2019 Arab Society for Plant Protection الجمعية العربية لوقاية النبات

مجلة وقاية النبات العربية، مجلد 37، عدد 2 (2019) 
الخارجة و الداخلة) تدريباتٍ نظريةً وعمليةً شملت جميع العمليات الزر اعية وطرق المكافحة وذلك ضمن 22 حقل ارشادي (20 حقلاً في سيوة و2 في الخارجة و الداخلة). تضمّن برنامج المكافحة المنفّ خلال شهورٍ المختلفة من السنة) مكافحة الآفات التي بدأت تنسبب بمشاكل خلال السنوات الأخيرة مثل ‘EphestiaCautella ‘Ephesteacalidellaguer ‘Batrachedraamydraula ‘Arenipsessabell ‘Parlatoriablancherdi ‘Oligonichusafrasiaticus (Coccotrypesdactyliperda و Amitermisdesertorium ،Oryzaephilussurinamens ،Rhynchophorusferrugineus 3) مكافحة الآفات التي تؤثر على التمور أثناء التخزين والتعبئة. كما شمل التدريب كيفية تحديد أعراض الإصابة بالآفات الحشرية المختلفة. وقد جرى إعداد 5

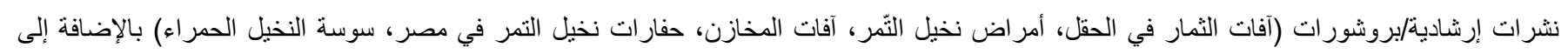

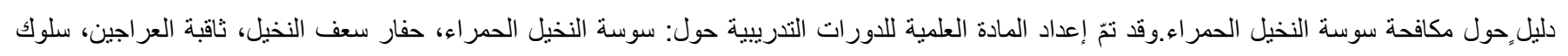
آفات وأمراض الثمار، الأعر اض الثائعة للإصـابة وطر ائق المكافحة (مثل: العمليات الوقائية، استخدام المبيدات، المصائد الضوئية، عوامل المكافحة الحيوية). وخلال فترة تنفيذ المشروع، فقد تمّ إعداد تقرير عن أهم الآفات والأمراض في مناطق عمل المشروع، وقد شمل الآفات التالية: سوسة النخيل الحمراء يليها دودة البلح الكبرى والصغرى ثم آفات المخازن وثاقبة نواة البلح؛ فضلاً عن تجهيز خطة عمل لمكافحتها.وجرى إعداد استبيان لجمع وتحليل البيانات حول أهم الآفات و الأمراض التي تصيب النخيل في واحة سيوة؛ وعلاوة على ذلك، فقد وضعت خطة عمل لمكافحة سوسة النخيل الحمر اء في تللك الواحة بمساعدة أحد الخبراء

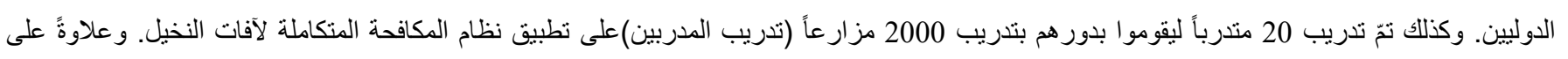
ذلك،فقد عولجت 1750 شجرة نخيلٍ مصابة في الواحات البحرية وسيوة باستخدام شنيور الحقن الذي يعمل بالبنزين. ونفّنت تجارب حقلية حول المكافحة المتكاملة لسوسة النخيل الحمر اء باستخدام مصائد الفيرمون التجميعي وحقن النخيل المصاب بالمبيدات الكيميائية ومتابعة رصد الآفة.

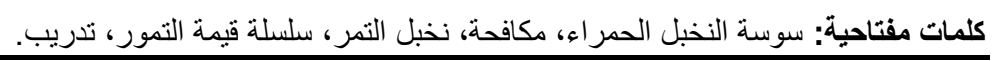

